Some notes on the history, previous to the official opening of the unit, are given.

The present set-up and organisation of the Centre are reported.

An account is given on the number of admissions and turnover of patients, general management, sources of income and running costs, together with a preview on the future of the Institute.

The main advantages and drawbacks derived from the autonomous setting up of the unit are discussed.

\title{
ORGANISATION OF AN AUTONOMOUS SPINAL UNIT AS PART OF A NATIONAL ACCIDENT INSURANCE ORGANISATION
}

\author{
By Professor Antonio Maglio \\ Spinal Injuries Center, Lido di Roma, Ostia
}

ThE Istituto Nazionale per l'Assicurazione contro gli Infortuni sul Lavoro (I.N.A.I.L.: Italian National Institute for Labour Accident Insurance) is an autonomous State organisation, the object of which is insurance against labour accidents and occupational diseases in industry and agriculture. Among jts tasks, therefore, is also that of providing medical and surgical treatment, orthopaedic and physiotherapeutic management as well as functional and professional rehabilitation of its insurants. The organisation was created by a law issued on 8 July I883; its present ruling is contained in a law issued in 1933 with a number of subsequent amendments.

The organisation is supervised and protected by the Ministry of Labour and Social Security; the Institute is presided over by a Chairman who is appointed by the President of the Italian Republic, and by a board of directors on which all the categories concerned are represented, i.e. industrial workers, agricultural workers, workers engaged in commercial activity, craftsmen, directors of industrial enterprises, representatives of the employers and representatives of certain Government departments and other State organisations concerned with social security.

Within the framework of its specific duties to treat and to rehabilitate with every useful procedure the victims of occupational accidents, I.N.A.I.L. has created, during the last few years, a network of large traumatological hospital centres in all the more important towns of Italy. These centres are run by I.N.A.I.L. directly. Other hospital wards or departments have been organised or developed in many smaller towns. Further, a certain number of centres has been created in order to answer certain particular therapeutic needs, such as the Centre at Budrio near Bologna for the application of prostheses in amputees and the Spinal Injuries Centre at Lido di Roma, Io years ago.

The aim of the Spinal Centre is to treat and rehabilitate every recent injury to the spinal cord which is brought to the Centre in the acute phase. Furthermore, 
the Centre takes charge of the rehabilitation of paraplegics who have undergone primary clinical treatment at other centres or traumatological hospitals or in neurological departments. Finally, the Centre is engaged in the study of problems connected with the clinical and sociological aspects of spinal lesions.

Over and above these fundamental aims of the Spinal Centre, a blue-print is now being studied within the framework of the further development of the National Institute for Labour Accident Insurance. This blue-print contemplates the institution of a spinal ward of 30 or 40 beds at every traumatological centre. These wards would be under the direct or indirect control of the Spinal Centre at Lido di Roma, which would act at first as a training centre and subsequently as a controlling and supervising organism.

This development scheme is not only prompted by transport difficulties due to the distance between the various towns of Italy but above all by the constant increase in the number of traumatic paraplegia cases. More than 300 new cases due to occupational accidents alone are added every year to the 5000 stabilised cases assisted throughout the national territory.

The economic and institutional organisation of the Spinal Centre is practically identical with that of a completely autonomous hospital as far as its clinical, social and re-educational purposes are concerned. It is only subject to the control of the Administrative Department which provides all the financial needs of the Centre either through the ordinary budget or through extraordinary expenditure, the latter being sanctioned in every individual instance by the Chairman or by the Board of Administrators.

The Spinal Centre is headed by a medical director who is at the same time physician in charge, and by an administrative office. In hospital centres with more than 120 beds the functions of medical director and physician in charge are usually carried out by two different persons.

The Director of the Centre, in his capacity as medical director, is responsible for the running of the Centre as a whole; he supervises its services and in particular the medical and nursing staff as well as the administrative and subordinate staff; he establishes the rules for the running of the technical, medical and hygienic services, as well as for the discipline of the patients, time-tables, etc. He also supervises the purchase of the medical material and equipment of the Centre and its use. Finally, he is responsible for the contact between the Centre and the superior authority of I.N.A.I.L., with the communal and provincial health services and with other medical organisations with which the Centre for some reason or other may have connections.

In his capacity as physician in charge, the Director of the Centre is responsible for the clinical and therapeutic approach in general. He supervises the running of the wards, establishes the general trend of medical activity and directs the clinical activity of the wards, including the emergency ward; furthermore the out-patient department and every other clinical activity of the Centre, as well as the scientific production of the Centre both as regards publications and as regards documentation.

The administrative side of the Centre consists of an administrative office, a steward's office, a book-keeping department and finance office.

The medical staff consists of three Heads of Departments, each of whom is responsible for one department, and of three assistants. In addition, there is a 
cardiologist, a pathologist, a head of laboratory, a radiologist, a physician, an anaesthetist and a specialist in physical medicine. Furthermore, there are outside consultants (ear, nose and throat specialist, gynaecologist, eye specialist) who are called in whenever necessary.

The medical staff is assisted by specialised auxiliary personnel, such as the physiotherapists who are trained for three years at a school run by I.N.A.I.L. itself. They attend to all the physiotherapeutic activities both in the wards and in the gymnasium. They are aided by assistant physiotherapists who are trained at the Spinal Centre itself.

The ordinary day-to-day tasks of the wards are carried out by professional nurses trained in courses approved by the State; these are aided by subaltern staff who carry out the less-skilled duties. The ideal proportion of subaltern staff to patients is about $\mathrm{I}: \mathrm{I}$.

The Centre is completed by an orthopaedic workshop where calipers are made to measure for every paraplegic trained to walk. Another workshop sees to the maintenance and repair of all the structures of the Centre. This workshop has a special department for the repair of wheelchairs.

The Villa Marina Spinal Injuries Centre has nowadays a capacity of I Io beds with an average turnover of about 200 paraplegics a year. In the Io years since its foundation, more than 1700 paraplegics and tetraplegics have been hospitalised. The present staff is slightly superior in numbers to the actual needs represented by the present number of inmates. This is due to the fact that a certain number of apprentices are at present being trained in view of a new Spinal Centre which will be built on an area of 80,000 square metres, with a built-up area of 2 I,000 square metres, a total cubature of 108,000 cubic metres and a capacity of more than 300 beds. This Centre should meet the needs of the present and of the immediate future and should also allow for short periods of hospitalisation for the check-ups of former patients and the treatment of relapses of all the paraplegics who come under the responsibility of I.N.A.I.L.

\title{
ISTITUTO FISIOTERAPICO E DI REEDUCAZIONE MOTORIA SELVAPIANA DEL CIRCEO-SABAUDIA, ITALY
}

\author{
By Dr. G. Pedacchia
}

THE Institute of Physiotherapy and Motor Re-education was founded in 1959 and is run along the lines suggested by Professor Antonio Maglio, director of the I.N.A.I.L. Centre for the Treatment of Paraplegics at Ostia, Lido, which is considered as the pilot Centre in Italy. The Institute is equipped and acts as a centre for paraplegics; at present it has a capacity of roo beds. At the beginning there were only 40 beds, which were increased gradually as follows: I960-6I, 50 beds; 1962-63, 70 beds; I964, 90 beds; until, in 1965, the present number of Ioo beds was reached.

Apart from patients suffering from traumatic or viral paraplegia or tetraplegia, also patients with multiple sclerosis, Parkinson's disease or sequelae of cerebral vascular lesions needing treatment and motor re-education are admitted. 